\title{
PENGARUH GAYA KEPEMIMPINAN, MOTIVASI DAN KEPUASAN KERJA TERHADAP KINERJA GURU (STUDI KASUS PADA SMK NEGERI 1 SIMPANG MAMPLAM KABUPATEN BIREUEN)
}

\author{
Abd. Fatah ${ }^{1)}$ dan Mohd. Ilyas ${ }^{2 *}$ \\ ${ }^{1}$ Guru SMK Negeri 1 Jeumpa Kabupaten Bireuen \\ ${ }^{2}$ Dosen FEB UNIKI Bireuen Aceh \\ *) email: ppsmm.uniki@gmail.com
}

DOI:

https://doi.org/10.55178/idm.v2i3.215

ABSTRAK

Article history

Received:

March 12, 2021

Revised:

March 18, 2021

Accepted:

March 22, 2021

Page:

$63-75$

Kata kunci:

Gaya kepmimpinan,

Motivasi, Kepuasan kerja

Kinerja guru
Tujuan penelitian ini adalah untuk mengetahui dan menganalisis; a) pengaruh gaya kepemimpinan terhadap kinerja guru, b) pengaruh motivasi terhadap kinerja guru, c) pengaruh kepuasan kerja terhadap kinerja guru, dan d) pengaruh secara simultan gaya kepemimpinan, motivasi, kepuasan kerja berpengaruh terhadap kinerja guru. Penelitian dilakukan di SMK Negeri 1 Simpang Mamplam Kabupaten Bireuen, dengan jenis penelitian deskriptif dan eksplanatori yang menjelaskan hubungan kausal dan pengaruh antar variabel melalui pengujian hipotesis, dengan metode analisis dengan pendekatan analisi jalur. Secara dsekriptif, diperoleh, a). Faktor gaya kepemimpinan, menurut persepsi guru sudah baik, mencapai 83,19\% walaupun masih harus dioptimalkan lagi. b). Faktor motivasi dianggap oleh sebagain guru sudah baik dalam mendukung kinerja guru. Skor penilaian guru atas motivasi mencapai 81,04 \%, c). Faktor kepuasan kerja, menurut penilaian guru, juga hampir mendekati optimal, yaitu mencapai $81,66 \%$, dan d). Tingkat Kinerja guru mencapai kategori baik, yakni 81,29 \%. Sedangkan secara eksplanatori, diperoleh hasil bahwa; 1).pengaruh faktor Gaya kepemimpinan terhadap Kinerja guru sebesar 24,53\%, 2).pengaruh faktor Motivasi terhadap Kinerja guru sebesar 19,12\%, 3) pengaruh Kepuasan kerja terhadap Kinerja guru di SMK Negeri 1 Simpang Mamplam Kabupaten Bireuen, yakni sebesar, yakni sebesar 16,95\%.

\section{Pendahuluan (Introduction)}

Upaya meningkatan kualitas pendidikan di sekolah pada dasarnya terjadi jika peningkatan kinerja guru terjadi secara optimal. Kualitas guru akan tercermin dalam proses belajar mengajar yang terlaksana sesuai dengan tuntutan kurikulum. Undang- undang Nomor 14 Tahun 2005 tentang Guru dan Dosen, Pasal 1 Ayat 1 mengamanatkan bahwa tugas utama guru yang dimaksud adalah mendidik, mengajar, membimbing, mengarahkan, melatih, menilai, dan mengevaluasi peserta didik pada pendidikan anak usia dini jalur pendidikan baik itu formal, pendidikan dasar, dan pendidikan menengah serta tugas tambahan yang relevan dengan fungsi sekolah.

Sekolah merupakan organisasi jasa yang tujuannya adalah melahirkan generasi yang mandiri dan siap terjun ditengah-tengah lingkungan sosial masyarakat. Tujuan mulia tersebut akan tercapai ketika adanya kerjasama yang baik dari segala unsur dan elemen sekolah (stakeholders). Keberhasilan sekolah dalam memberdayakan segala unsur dan elemen yang ada dipengaruhui oleh pimpinan di sekolah yakni kepala sekolah. Keberhasilan kepala sekolah adalah keberhasilan bawahan (guru, staf, kebersihan, satpam dan lainlain) dan keberhasilan bawahan adalah keberhasilan kepala sekolah. Hal ini harus menjadi budaya dan komitmen bersama dalam organisasi sekolah.

Tugas utama guru dalam proses pendidikan, dalam rangka melihat mkinerja, yakni upaya keras dan sungguh-sunguh dalam memberikan pengaruh dan warna yang kuat bagi pembinaan perilaku dan kepribadian siswa. Oleh karena itu perilaku guru hendaknya dapat dikembangkan, sehingga memberikan 
pengaruh yang berkesan, baik bagi siswa, orang tua, masyarakat dan sebagai pusat perhatian dalam meningkatkan, mengembangkan tujuan organisasi serta mendidik, mengajar, membimbing, mengarahkan, serta memandu peserta didik menuju kedewasaan mental, spiritual maupun fisik-biologis (Surya, 2004; Yamin dan Maisah, 2010; Rusyan, 2013).

Pemerintah telah melakukan berbagai upaya untuk meningkatkan kinerja guru, diantaranya melalui kegiatan penataran, bimbingan teknis, diklat, penyetaraan pendidikan dan peningkatan penghasilan melalui program sertifikasi guru, namun kenyataannya masih belum bisa meningkatkan kinerja guru secara maksimal, khususnya dalam mengelola pembelajaran. Hal ini senada dengan hasil Uji Kompetensi Guru (UKG) SMK 2019 dengan nilai rata-rata 50,39 untuk SMK Kabupaten Bireuen, 51,88 untuk Provinsi aceh dan sebagai perbandingan nilai UKG SMK untuk Provinsi DKI Jakarta adalah 60,08 (Neraca Pendidikan Daerah, Kemendikbud, 2019).

Terlepas dari adanya kontraversi dari hasil UKG 2019, hampir seluruh SMK se-Aceh bersama Dinas Pendidikan Aceh dan Majelis Pendidikan Daerah melakukan upaya sungguh-sungguh dalam upaya peningkatan kinerja guru melalui diklat-diklat serta kegiatan musyawarah guru mata pelajaran (MGMP) yang adakalanya nilai hasil UKG berbeda dengan kinerja guru yang terlihat pada kenyataannya di lapangan.

Karena yang diharapkan, seperti diungkapkan oleh Nana Sudjana dkk, (2004:107) tentang kompetensi Kinerja guru, yaitu seorang guru harus mampu; 1). Menguasai bahan yang akan diajarkan. 2). Mengelola program belajar mengajar, 3). Mengelola kelas, 4). Menggunakan media/sumber pelajaran, 5). Menguasai landasan-landasan kependidikan, 6). Mengelola interaksi belajar mengajar, 7). Menilai prestasi siswa, 8). Mengenal fungsi dan program bimbingan dan penyuluhan, 9). Mengenal dan menyelenggarakan administrasi sekolah, dan 10). Memahami prinsip-prinsip dan menafsirkan hasil-hasil penelitian.

Kinerja Guru merupakan unjuk kerja yang dilakukannya dalam melaksanakan tugasnya sebagai pendidik. Kualitas kinerja guru akan sangat menentukan pada kualitas hasil pendidikan, karena guru merupakan pihak yang paling banyak bersentuhan langsung dengan siswa dalam proses pendidikan/ pembelajaran di sekolah. Sudah banyak teori dan hasil penelitian yang mengangkat sekaligus menganalisis factor-faktor yang mempengaruhi kinerja guru bidang studi. Terdapat beberapa kesimpulan, diantaranya terkait dengan kepemimpinan yang ditunjukkan oleh Kepala Sekolah, faktor motivasi dari diri guru, budaya sekolah, penghasilan, dan juga kepuasan kerja menjadi seorang guru.

Kepala sekolah yang berhasil terlihat dari gaya kepemimpinannya yang mampu mempengaruhi dan menggerakan stakeholders pendidikan untuk sama-sama menggapai kesuksesan sekolah yang diikat dalam satu visi yang sama. Keberhasilan kepala sekolah sebagai pemimpin terlihat dari tujuh indikator yang melekat dalam dirinya, yaitu 1). Kepala Sekolah sebagai Educator, 2).Kepala Sekolah sebagai Manajer, 3). Kepala Sekolah sebagai Administrator. 4). Kepala Sekolah sebagai Supervisor, 5).Kepala Sekolah sebagai Leader, 6).Kepala Sekolah sebagai Inovator, 7). Kepala Sekolah sebagai Motivator.

Kepala sekolah memiliki gaya kepemimpinan yang berbeda-beda. Gaya kepemimpinan Kepala sekolah merupakan gaya kemampuan dari seorang kepala sekolah dalam mempengaruhi dan menggerakkan bawahan pada suatu organisasi atau lembaga sekolah guna tercapainya tujuan sekolah. Pemilihan gaya kepemimpinan yang tepat akan memberikan motivasi kerja kepada bawahan, sehingga bawahan akan merasa puas. Sebaliknya tidak jarang kesalahan dalam pemilihan gaya kepemimpinan berakibat kegagalan kepemimpinan seseorang dalam sekolah dan berdampak pada mutu pendidikan sekolah tersebut.

Sekolah sebagai sebuah organisasi, manajemennya dipimpin oleh seorang Kepala Sekolah. Faktor kepemimpimpinan kepala sekolah berkaitan dengan upaya peningkatan motivasi kerja guru. Pada umumnya, kepala sekolah di Indonesia belum dapat dikatakan sebagai manajer profesional. Hal ini disinyalir pula oleh laporan Bank Dunia bahwa salah satu penyebab makin menurunnya mutu pendidikan di persekolahan di Indonesia adalah kurang profesionalnya peran kepala sekolah (E.Mulyasa, 2003:42).

Disamping itu, hal yang sangat terkait dalam mana guru mampu berprestasi, yakni sejauhmana mereka memiliki motivasi untuk maju, untuk berbuat dan menghasilkan kerja yang baik. Motivasi kerja yang tinggi dalam sebuah organisasi sekolah akan berdampak positif yaitu tercapainya tujuan yang telah ditentukan oleh organisasi sekolah. Agar motivasi kerja dapat dioptimalkan dalam organisasi sekolah maka perlu diketahui faktor-faktor yang dapat mempengaruhi motivasi kerja itu. Faktor-faktor itu meliputi faktor internal yang bersumber dari dalam individu dan faktor eksternal yang bersumber dari luar individu. Faktor internal seperti sikap terhadap pekerjaan, bakat, minat, kepuasan, pengalaman, dan lain-lain serta faktor dari luar individu yang bersangkutan seperti pengawasan, gaji, lingkungan kerja, kepemimpinan (Wahjosumidjo, 2001: 42). 
Lalu, hal yang juga sangat menarik untuk diukur adalah sejauhmana guru memiliki kepuasan kerja (job satisfaction). Karena manakala guru belum mememiliki kepuasan dalam bekerja, tidak bisa diharapkan dapat dihasilkan sumber daya manusia yang baik sebagai hasil kerja guru, yakni peserta didik yang berkualitas. Hal ini secara langsung maupun tidak langsung akan berpengaruh terhadap produktivitas kerja. Suatu gejala yang dapat membuat rusaknya kondisi organisasi sekolah adalah rendahnya kepuasan kerja guru. Faktor penyebabnya adalah timbulnya gejala seperti kemangkiran, malas bekerja, banyaknya keluhan guru, rendahnya prestasi kerja, rendahnya kualitas pengajaran, indisipliner guru dan gejala negatif lainnya. Sebaliknya kepuasan yang tinggi diinginkan oleh Kepala Sekolah. Hal ini dapat dikaitkan dengan hasil positif yang mereka harapkan.

Kepuasan kerja yang tinggi menandakan bahwa sebuah organisasi sekolah telah dikelola dengan baik dan manajemen yang efektif. Kepuasan kerja yang tinggi menunjukkan kesesuaian antara harapan guru dengan imbalan yang disediakan oleh organisasi. Tetapi pada kenyataannya bahwa tidak semua pegawai mempunyai kepuasan kerja yang tinggi, justru mengalami penurunan. Suatu organisasi banyak mengalami permasalahan yang timbul pada kepuasaan kerja yang rendah, sehingga menimbulkan dampak negatif seperti produktivitas rendah, semangat kerja rendah, guru yang sering absen, dan datang terlambat.

Sesuai dengan hasil survei di SMK Negeri 1 Simpang Mamplam Kabupaten Bireuen bahwa terdapat beberapa catatan yang berkemungkinan berpengaruh terhadap kinerja guru, yang disebabkan antara lain: (1) Sedikit guru berstatus PNS dan banyak guru yang berstatus kontrak, (2) Kurangnya sumber dana pendidikan, (3) Kurangnya penyediaan sarana pembelajaran, (4) Kurang partisipasi aktif guru dalam forum MGMP disebabkan jarak sekolah yang jauh dari ibu kota Kabupaten yang menjadi pusat kegiatan. (5) Kurangnya dukungan masyarakat atau orang tua /wali siswa terhadap kegiatan sekolah. (6) Kurangnya dukungan sumberdaya sulit bagi kepala sekolah untuk menjadi manajer yang handal, (7) Rendahnya keinginan siswa untuk meningkatkan kemampuan dalam mengikuti pembelajaran dan ekstrakurikuler lainnya.

\section{Tinjauan Literatur (Literature Review)}

\section{a. Pengaruh Kepemimpinan Kepala Sekolah terhadap Kinerja Guru}

Gaya Kepemimpinan merupakan suatu cara yang dimiliki oleh seseorang dalam mempengaruhi sekelompok orang atau bawahan untuk bekerja sama dan berdaya upaya dengan penuh semangat dan keyakinan untuk mencapai tujuan yang telah ditetapkan. Artinya, gaya kepemimpinan dapat menuntun pegawai untuk bekerja lebih giat, lebih baik, lebih jujur dan bertanggungjawab penuh atas tugas yang diembannya sehingga meraih pekerjaan dapat diselesaikan dengan baik. Hubungan pimpinan dan bawahan dapat diukur melalui penilaian pekerja terhadap gaya kepemimpinan para pemimpin dalam mengarahkan dan membina para bawahannya untuk melaksanakan pekerjaan (Hadari, 2003).

Gaya Kepemimpinan kepala sekolah yang efektif dapat mengoptimalkan kinerja guru. Hal ini sesuai dengan pendapat Arief $(1993 ; 614)$, yang menyatakan bahwa gaya kepemimpinan yang efektif adalah gaya kepemimpinan yang berhasil dalam melaksanakan peranannya sebagai pemimpin. Keberhasilan tersebut dapat diukur dari kinerja guru yang meningkat.

Keberhasilan suatu organisasi baik sebagai keseluruhan maupun berbagai kelompok dalam suatu organisasi tertentu, sangat tergantung pada efektivitas kepemimpinan yang terdapat dalam organisasi yang bersangkutan. Dapat dikatakan bahwa mutu kepemimpinan yang terdapat dalam suatu organisasi memainkan peranan yang sangat dominan dalam keberhasilan organisasi tersebut dalam menyelenggarakan berbagai kegiatannya terutama terlihat dalam kinerja para pegawainya (Siagian, 2003).

Pemimpin yang terdapat pada organisasi harus memiliki kelebihan-kelebihan dibandingkan dengan bawahannya, sehingga dapat menunjukkan kepada bawahannya untuk bergerak, bergiat, berdaya upaya yang tinggi untuk mencapai tujuan-tujuan yang telah ditetapkan. Akan tetapi hanya mengerahkan seluruh pegawai saja tidak cukup, sehingga perlu adanya suatu dorongan agar para pegawainya mempunyai minat yang besar terhadap pekerjaanya. Atas dasar inilah selama perhatian pemimpin diarahkan kepada bawahannya, maka kinerja pegawainya akan tinggi. Sebagaimana yang dikemukakan Karjadi (1983), pemimpin adalah menggerakkan orang-orang lain agar orang-orang dalam suatu organisasi yang telah direncanakan dan disusun terlebih dahulu dalam suasana moralitas yang tinggi, dengan penuh semangat dan kegairahan dapat menyelesaikan pekerjaannya masing-masing dengan hasil yang diharapkan.

Semua pemimpin tentu saja tidak sama antara satu dan yang lainnya. Trait (sifat) mereka mungkin serupa dalam beberapa hal, namun mereka dapat sangat berbeda dalam gaya atau pendekatan kepemimpinan. 
Meskipun terdapat begitu banyak variasi gaya kepemimpinan mengingat begitu banyak pemimpin. Terdapat banyak gaya kepemimpinan yang diperankan dari seorang pemimpin dalam organisasi. Diantaranya adalah kepemimpinan transformasional. Gaya ini sering kali diidentifikasikan sebagai gaya tunggal yang paling efektif. Gaya ini pertama kali dijelaskan pada akhir 1970-an dan kemudian dikembangkan oleh peneliti Bernard M. Bass. Yang menjelaskan bahwa pemimpin transformasional mampu memotivasi dan menginspirasi pengikut serta mengarahkan perubahan positif dalam kelompok. Para pemimpin dengan gaya ini cenderung cerdas secara emosional, energik, dan penuh gairah. Mereka tidak hanya berkomitmen untuk membantu organisasi mencapai tujuannya, tetapi juga membantu anggota kelompok memenuhi potensi mereka.

Penelitian menunjukkan bahwa gaya kepemimpinan ini menghasilkan kinerja yang lebih tinggi dan kepuasan kelompok yang lebih baik daripada gaya kepemimpinan lainnya. Satu studi juga menemukan bahwa kepemimpinan transformasional menyebabkan peningkatan kesejahteraan di antara anggota kelompok.

\section{b. Pengaruh Motivasi terhadap Kinerja Guru}

Salah satu faktor yang mempengaruhi kinerja yaitu faktor motivasi, dimana motivasi merupakan kondisi yang diinginkan. Menunjukkan bahwa semakin kuat motivasi kerja, kinerja karyawan akan semakin tinggi. Hal ini berarti bahwa setiap peningkatan motivasi kerja akan memberikan peningkatan yang sangat berarti bagi peningkatan kinerja dalam melaksanakan pekerjaannya, Rivai (2003:459)

Motivasi untuk melaksanakan pekerjaan dengan baik akan muncul apabila pekerjaan yang dikerjakannya mempunyai nilai atau berarti bagi pegawai yang bersangkutan. Mangkunegara (2009; 67) mengatakan factor-faktor yang mempengaruhi kinerja adalah faktor motivasi. Hal senada disebutkan Buchari Hainun (2009; 50); "motivasi merupakan syarat pokok yang istimewa bagi manusia yang berpengaruh terhadap tingkat dan mutu kerja, disamping lingkungan dan iklim organisasi". Dan dijelaskan juga oleh Sudarmayanti (2007; 233), bahwa motivasi adalah kesedian mengeluarkan tingkat upaya tinggi kearah tujuan organisasi yang dikondisikan oleh kemampuan upaya itu untuk memenuhi kebutuhan individual.

Faktor motivasi memiliki keterkaitan dengan kinerja, dikarenakan apabila seorang guru merasa termotivasi oleh apa yang akan dilakukannya kepada sekolah akan memberikan kinerja yang maksimal. Banyak dari indikator dalam variabel motivasi yang mendukung peningkatan kinerja guru, seperti pemberian penghargaan yang dilakukan sekolah kepada guru yang berprestasi akan memacu guru tersebut untuk lebih meningkatkan kinerjanya. Hal ini diungkapkan oleh Mangkunegara $(2005,61)$ bahwa "motivasi terbentuk dari sikap (attitude) karyawan dalam menghadapi situasi kerja di perusahaan (situation). Motivasi merupakan kondisi atau energi yang menggerakkan diri karyawan yang terarah atau tertuju untuk mencapai tujuan organisasi perusahaan. Sikap mental karyawan yang pro dan positif terhadap situasi kerja itulah yang memperkuat motivasi kerjanya untuk mencapai kinerja maksimal”.

Menurut Herzberg (dalam Munandar, 2010), bahwa karyawan termotivasi untuk bekerja disebabkan oleh dua faktor: a. Faktor intrinsik yaitu faktor daya dorong yang timbul dari dalam diri karyawan, berupa Pekerjaan itu sendiri (the work it self), Kemajuan (advancement), Tanggung jawab (responsibility), Pengakuan (recognition), Pencapaian (achievement). Dan faktor ekstrinsik yaitu faktor pendorong yang datang dari luar diri seseorang terutama dari organisasi tempatnya bekerja. Mencakup administrasi dan kebijakan organisasi, Penyeliaan Tingkat kewajaran, Kewajaran gaji yang diterima, Hubungan antar pribadi dan Kondisi kerja.

\section{c. Pengaruh Kepuasan Kerja terhadap Kinerja Guru}

Pada dasarnya setiap individu memiliki tingkat kepuasan yang berbeda-beda sesuai dengan sistem nilai yang berlaku pada dirinya. Semakin banyak aspek yang terkandung di dalam suatu pekerjaan yang sesuai dengan keinginan individu maka semakin tinggi tingkat kepuasan yang dirasakan dan sebaliknya. Seperti yang dijelaskan oleh Handoko dalam Sutrisno (2009; 79), bahwa kepuasan kerja adalah keadaan emosional yang menyenangkan atau tidak menyenangkan bagi karyawan memandang pekerjaan mereka. Kepuasan kerja mencerminkan perasaan seseorang terhadap pekerjaannya. Ini tampak dalam sikap positif karyawan terhadap pekerjaan dan segala sesuatu yang dihadapi di lingkungan kerjanya.

Dalam kaitan kepuasan kerja dengan kinerja, Luthans (2011) menyatakan bahwa meskipun hasil analisis dari berbagai riset menunjukkan bahwa hubungan antara kepuasan kerja dengan kinerja adalah kuat, namun tidak sebesar pengaruh dari sifat individu terhadap kinerja. Juga penelitian Roelen, Koopmans and Groothoff (2008) menyebutkan bahwa variasi tugas, kondisi kerja, beban kerja, dan perspektif karir menentukan bagian yang lebih besar dalam kepuasan kerja. Jenaibi (2010) dalam penelitiannya mengatakan 
bahwa kepuasan kerja itu berdasarkan manajemen yang efektif, komunikasi, fasilitas, keuntungan, gaji, teknologi dan pekerjaan di masa depan. Hal ini didukung pula oleh Keiningham, et. al (2006) yang mengemukakan bahwa adanya hubungan antara kepuasan tenaga kerja dan kinerja bisnis.

Menurut Smith, Kendall \& Hulin (dalam Luthans, 2006) ada beberapa dimensi kepuasan kerja yang dapat digunakan untuk mengungkapkan karakteristik penting mengenai pekerjaan, dimana orang dapat meresponnya. Dimensi itu adalah: Pekerjaan itu sendiri (Work It Self), factor atasan (Supervision), Teman sekerja (Workers), Promosi (Promotion) dan income (Gaji/upah) yang dianggap layak atau tidak diterima dari hasil kerjanya.

Berdasarkan uraian di atas penulis dapat menggambarkan kerangka pemikiran sebagai berikut :

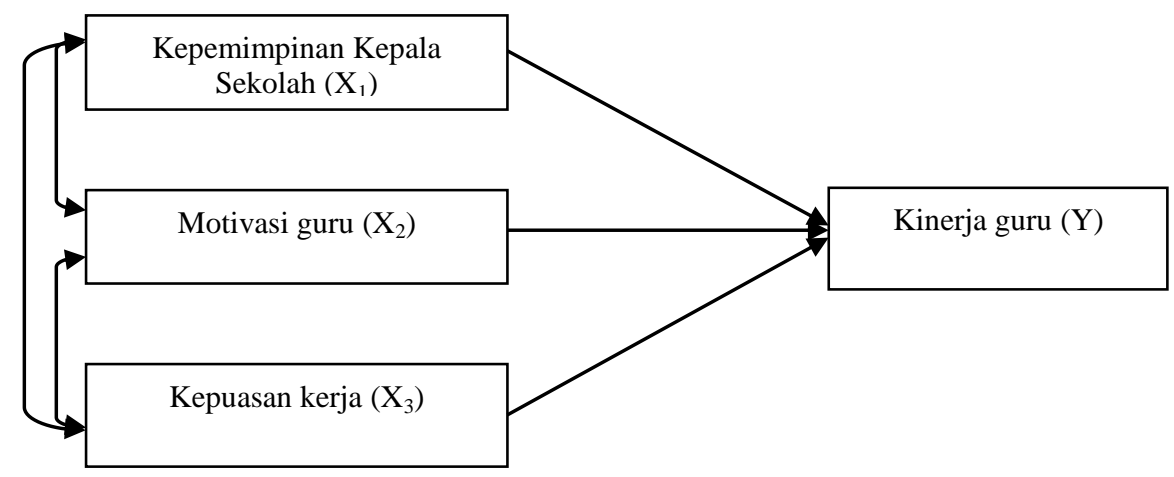

Gambar 1. Kerangka Pemikiran

\section{Metode Penelitian (Methodology)}

\section{a. Metode dan Variabel Penelitian}

Penelitian ini menggunakan penelitian eksplanatori yang menjelaskan hubungan kausal dan pengaruh antar variabel melalui pengujian hipotesis, yakni menjelaskan pengaruh variabel bebas yakni Gaya Kepemimpinan, Motivasi guru, Kepuasan Kerja guru terhadap variabel tidak bebas, yaitu Kinerja Guru. Penelitian mengambil unit analisisnya adalah pada sejumlah 48 guru SMKN 1 Simpang Mamplam Kabupaten Bireuen.

Adapun variabel, dimensi dan indikator pengukurnya di definisikan berikut ini.

Tabel 1. Operasional Variabel Penelitian

\begin{tabular}{|c|c|c|}
\hline Variabel & Defenisi Konsep & Dimensi \\
\hline $\begin{array}{l}\text { Kepemimpinan } \\
\text { Kepala Sekolah } \\
\left(\mathrm{X}_{1}\right)\end{array}$ & $\begin{array}{l}\text { Merupakan cara yang diambil seseorang dalam rangka } \\
\text { mempraktekkan kepemimpinannya. } \\
\text { Umam, }(2010: 278)\end{array}$ & $\begin{array}{l}\text { a. Gaya Kepemimpinan Autokratis } \\
\text { b. Gaya Kepemimpinan Birokratik } \\
\text { c. Gaya Kepemimpinan Diplomatis } \\
\text { d. Gaya Kepemimpinan Partisipatif } \\
\text { e. Gaya Kepemimpinan free rein jender }\end{array}$ \\
\hline $\begin{array}{l}\text { Motivasi Kerja } \\
\left(\mathrm{X}_{2}\right)\end{array}$ & $\begin{array}{l}\text { Yaitu yang menjadi dasar semangat seseorang } \\
\text { melakukan sesuatu untuk mencapai tujuan. } \\
\text { Winardi }(2010 ; 61)\end{array}$ & $\begin{array}{ll}\text { a. Internal } \\
\text { b. Eksternal }\end{array}$ \\
\hline $\begin{array}{l}\text { Kepuasan Kerja } \\
\left(\mathrm{X}_{3}\right)\end{array}$ & $\begin{array}{l}\text { Kondisi psikis yang menyenangkan yang dirasakan } \\
\text { oleh pekerja/pegawai di dalam suatu lingkungan } \\
\text { pekerjaan atas peranannya dalam organisasi dan } \\
\text { kebutuhannya terpenuhi dengan baik. } \\
\text { Gibson et al }(2008 ; 150)\end{array}$ & $\begin{array}{ll}\text { a. Upah } \\
\text { b. Pekerjaan } \\
\text { c. Kesempatan Promosi } \\
\text { d. Penyelia } \\
\text { e. Rekan Kerja }\end{array}$ \\
\hline $\begin{array}{l}\text { Kinerja Guru } \\
\text { (Y) }\end{array}$ & $\begin{array}{l}\text { Hasil kerja secara kualitas dan kuantitas yang } \\
\text { Dicapai oleh seorang pegawai dalam melaksanakan } \\
\text { fungsinya Sesuai dengan tanggung jawab yang } \\
\text { diberikan kepadanya } \\
\text { (Departemen Pendidikan Nasional ; 2008) }\end{array}$ & $\begin{array}{l}\text { a. Penyusunan Rencana Pelaksanaan } \\
\text { Pembelajaran } \\
\text { b. Pelaksanaan Kegiatan Pembelajaran } \\
\text { c. Penilaian Hasil Belajar }\end{array}$ \\
\hline
\end{tabular}

\section{b. Populasi dan Sampel Penelitian}

Populasi penelitian adalah seluruh guru pada SMKN 1 Simpang Mamplam Kabupaten Bireuen, tahun ajaran 2020-2021, yang berjumlah 48 orang. Karena jumlahnya terbatas, maka digunakan sampel jenuh yakni semua unit populasi. 
Sekolah Menengah Kejuruan (SMK) Negeri 1 Simpang Mamplam adalah satu-satunya SMK Negeri kelompok pertanian di Kabupaten Bireuen yang pendiriannya tahun 2012 yang lokasinya terletak di pinggir jalan raya Banda Aceh km 182 Cot Bate Geulungku kecamatan Simpang Mamplam Kabupaten Bireuen. Pada SMK Negeri 1 Simpang Mamplam mempunyai 4 (empat) program keahlian yaitu Mekanisasi Pertanian, Agribisnis Hasil Pertanian dan Agribisnis Produksi Pertanian. Namun dalam kurun waktu empat tahun ini, banyak permintaan atau aspirasi masyarakat Simpang dan Teknik Sepeda Motor.

\section{c. Metode Analisis}

Teknik analisis data dalam peneltian kuantitatif mengunakan pendekatan metode dan alat statistik parametrik. Karena penelitian ini ingin mengetahui jawaban atas hipotesis berdasarkan uji statistik, sehingga penelitian ini menggunakan statistik inferensi. Misbahuddin dan Hasan (2013:2), menyatakan statistik inferensi adalah bagian statistik yang mempelajari penafsiran dan penarikan kesimpulan yang berlaku secara umum dari data yang tersedia. Data penelitian selanjutnya dianalisis secara deskriptif, dan verifikatif yang diikuti dengan menguji persyaratan analisis dan menguji hipotesis penelitian dengan menggunakan analisis model jalur (Path Analysis).

Analisis jalur merupakan pengembangan langsung bentuk regresi berganda dengan tujuan untuk memberikan estimasi tingkat kepentingan (magnitude) dan signifikansi (significance) hubungan sebabakibat hipotetikal dalam seperangkat variabel" (Paul Webley; 1997, dalam Marwan Hamid, dkk; 2019).

Menurut Marwan Hamid, dkk (2019:10) bahwa model analisis jalur digunakan untuk menganalisis pola hubungan antar variabel dengan tujuan untuk mengetahui pengaruh langsung maupun tidak langsung seperangkat variabel bebas (eksogen) terhadap variabel terikat (endogen). Model analisis jalur yang dibicarakan adalah pola hubungan sebab-akibat. Oleh karena itu, rumusan masalah penelitian dalam kerangka analisis jalur hanya berkisar pada variabel bebas $\left(\mathrm{X}_{1}, \mathrm{X}_{2}, \ldots, \mathrm{X}_{\mathrm{k}}\right)$ yang berpengaruh terhadap variabel terikat $\mathrm{Y}$ atau berapa besar pengaruh kausal langsung, kausal tidak langsung, kausal total maupun simultan seperangkat variabel bebas $\left(\mathrm{X}_{1}, \mathrm{X}_{2}, \ldots, \mathrm{X}_{\mathrm{k}}\right)$ terhadap variabel terikat $\mathrm{Y}$.

Model struktural secara umum dapat digambarkan dengan persamaan sebagai berikut : $\mathrm{Y}=f\left(\mathrm{X}_{1}, \mathrm{X}_{2}, \mathrm{X}_{3}\right)$. Diagram jalur dan persamaan struktural penelitian ini adalah seperti terlihat pada Gambar 1 berikut :

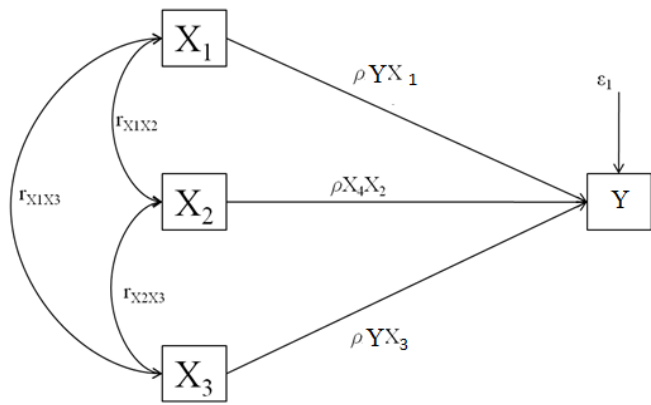

Gambar 1 Diagram Jalur Penelitian

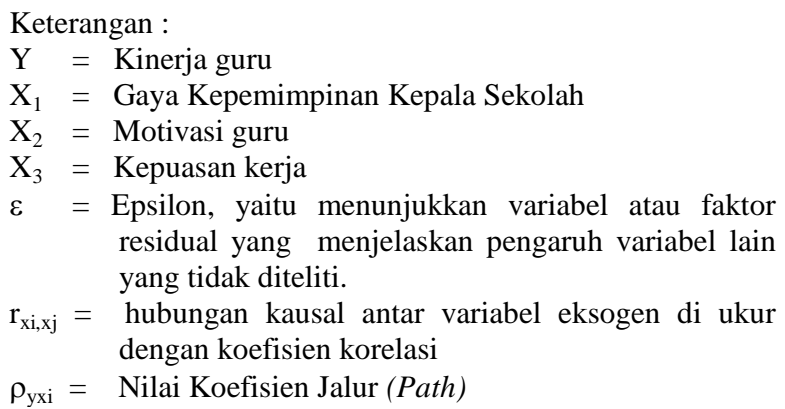

Keterangan :

$\mathrm{Y}=$ Kinerja guru

$\mathrm{X}_{2}=$ Motivasi guru

$\mathrm{X}_{3}=$ Kepuasan kerja

$\varepsilon=$ Epsilon, yaitu menunjukkan variabel atau faktor residual yang menjelaskan pengaruh variabel lain yang tidak diteliti.

$\rho_{\mathrm{yxi}}=$ Nilai Koefisien Jalur (Path)

\section{Hasil dan Pembahasan (Results and Discussion)}

\section{a. Deskripsi Karakteristik Responden}

Tabel 2. Karakteristik Responden (Guru SMKN 1 Sp. Mamplam Kab. Bireuen)

\begin{tabular}{|l|l|c|c|}
\hline \multicolumn{2}{|c|}{ Karakteristik } & Jumlah & Persentase \% \\
\hline \multirow{4}{*}{ Umur } & $\leq 25$ tahun & 1 & $2,08 \%$ \\
\cline { 2 - 4 } & $26-35$ tahun & 27 & $56,25 \%$ \\
\cline { 2 - 4 } & $36-55$ tahun & 17 & $35,42 \%$ \\
\cline { 2 - 4 } & $\geq 55$ tahun & 3 & $6,25 \%$ \\
\hline \multirow{3}{*}{ Jenis Kelamin } & Laki - Laki & 12 & $25,00 \%$ \\
\cline { 2 - 4 } & Perempuan & 36 & $75,00 \%$ \\
\hline \multirow{3}{*}{$\begin{array}{l}\text { Pendidikan } \\
\text { Terakhir }\end{array}$} & SMA/SMK & 0 & $0,00 \%$ \\
\cline { 2 - 4 } & D3 & 1 & $2,08 \%$ \\
\cline { 2 - 4 } & S1 & 44 & $91,67 \%$ \\
\cline { 2 - 4 } & S2 & 3 & $6,25 \%$ \\
\hline Lama Bekerja & $\leq 5$ tahun & 22 & $45,83 \%$ \\
\hline
\end{tabular}




\begin{tabular}{|l|l|c|c|}
\hline & $6-9$ tahun & 10 & $20,83 \%$ \\
\cline { 2 - 4 } & $\geq 10$ tahun & 16 & $33,33 \%$ \\
\hline \multirow{2}{*}{ Status } & PNS & 14 & $29,17 \%$ \\
\cline { 2 - 4 } Kepegawaian & Non PNS & 34 & $70,83 \%$ \\
\hline \multicolumn{2}{|c|}{ Jumlah Responden } & 48 & $100 \%$ \\
\hline
\end{tabular}

Sumber : Data Primer yang diolah, 2021

\section{b. Pengujian Instrumen Penelitian}

Pada umumnya dalam penelitian survey, pengumpulan data tentang variable penelitian menggunakan angket atau kuesioner. Intrumen dalam angket dimunculkan atas dasar dimensi dan indikator variabel yang secara substansi atau teoritis dapat dan sesuai dengan konsep variabel yang digunakan. Namun untuk lebih meyakinkan bahwa butir-butir pernyataan dalam angket tentang indiator variabel tersebut terukur, akurat dan dapat dihandalkan, maka perlu dilakukan pengecekan. Dalam hal ini adalah pengujian secara statistik non parametrik, yakni uji validitas dan reliabilitas instrumen. Karena benar tidaknya data, tergantung dari baik tidaknya instrumen pengumpulan data.

Validitas adalah tingkat keandalah dan kesahihan alat ukur yang digunakan. Intrumen dikatakan valid berarti menunjukkan alat ukur yang dipergunakan untuk mendapatkan data itu valid atau dapat digunakan untuk mengukur apa yang seharusnya di ukur (Sugiyono, 2004:137). Dengan demikian, instrumen yang valid merupakan instrumen yang benar-benar tepat untuk mengukur apa yang hendak di ukur. Dan uji reliabilitas berguna untuk menetapkan apakah instrumen yang dalam hal ini kuesioner dapat digunakan lebih dari satu kali, paling tidak oleh responden yang sama akan menghasilkan data yang konsisten. Dengan kata lain, reliabilitas instrumen mencirikan tingkat konsistensi.

Hasilnya diperoleh berikut ini:

Tabel 3. Uji Coba Validitas Instrumen untuk Gaya Kepemimpinan Kepala Sekolah

\begin{tabular}{|c|l|c|c|c|}
\hline Butir & \multicolumn{1}{|c|}{ Pernyataan r-hitung } & r-min & Keputusan \\
\hline 1 & $\begin{array}{l}\text { Pimpinan dengan kekuasaannya memberikan } \\
\text { tugas kepada pegawai. }\end{array}$ & 0,552 & 0,300 & Valid \\
\hline 2 & $\begin{array}{l}\text { Pegawai menyelesaikan tugas sesuai dengan } \\
\text { tugas yang diberikan. }\end{array}$ & 0,642 & 0,300 & Valid \\
\hline 3 & $\begin{array}{l}\text { Pimpinan memberikan tugas kepada pegawai } \\
\text { sesuai dengan prosedur yang sudah ditetapkan. }\end{array}$ & 0,832 & 0,300 & Valid \\
\hline 4 & $\begin{array}{l}\text { Pimpinan berkomunikasi dengan baik kepada } \\
\text { pegawai. }\end{array}$ & 0,808 & 0,300 & Valid \\
\hline 5 & $\begin{array}{l}\text { Pimpinan memberikan semangat kepada } \\
\text { pegawai. }\end{array}$ & 0,614 & 0,300 & Valid \\
\hline 6 & $\begin{array}{l}\text { Pegawai termotivasi untuk menjalankan } \\
\text { tugasnya dengan baik. }\end{array}$ & 0,606 & 0,300 & Valid \\
\hline 7 & $\begin{array}{l}\text { Pimpinan mengikutsertakan pegawai dalam } \\
\text { memberikan pendapat. }\end{array}$ & 0,483 & 0,300 & Valid \\
\hline 8 & $\begin{array}{l}\text { Pegawai merasa pendapatnya dihargai oleh } \\
\text { pimpinan. }\end{array}$ & 0,468 & 0,300 & Valid \\
\hline 9 & $\begin{array}{l}\text { Pegawai menjalankan tugasnya dengan penuh } \\
\text { tanggung jawab. }\end{array}$ & 0,608 & 0,300 & Valid \\
\hline
\end{tabular}

Sumber: Hasil Olahan Data dengan program SPSS (2021)

Dari hasil perhitungan validitas variabel diatas, tampak semua butir pernyataan dinyatakan valid, karena nilai $\mathrm{r}_{\text {-hitung }}$ semua diatas kriteria $\mathrm{r}$-minimal $=0,300$. Sehingga semua butir pernyataan dalam angket yang mengukur variabel Kepemimpinan Kepala sekolah, dinyatakan valid.

Hal yang sama dilakukan uji validitas variabel Motivasi kerja guru. Tampak pada tabel 4, dari ke-empat butir pernyataan, semua dinyatakan valid, karena nilai $\mathrm{r}_{\text {-hitung }}$ semua diatas kriteria r-minimal. Sehingga dapat mengukur variabel Motivasi kerja guru.

Tabel 4. Uji Coba Validitas Instrumen untuk Variabel Motivasi Guru

\begin{tabular}{|c|l|c|c|c|}
\hline Butir & \multicolumn{1}{|c|}{ Pernyataan } & r-hitung & r-min & Keputusan \\
\hline 1 & $\begin{array}{l}\text { Tanggung jawab kerja yang di emban cukup } \\
\text { jelas. }\end{array}$ & 0,895 & 0,300 & Valid \\
\hline 2 & Sebagai guru saya memiliki minat dalam & 0,780 & 0,300 & Valid \\
\hline
\end{tabular}




\begin{tabular}{|c|l|c|c|c|}
\hline & mengajar. & & & Valid \\
\hline 3 & $\begin{array}{l}\text { Saya merasa nyaman dalam menyelesaikan tugas } \\
\text { dengan lingkungan yang bersih dan nyaman. }\end{array}$ & 0,725 & 0,300 & Valid \\
\hline 4 & $\begin{array}{l}\text { Sekolah memenuhi fasilitas keamanan dan } \\
\text { keselamatan dalam menjalankan pekerjaan saya. }\end{array}$ & 0,694 & 0,300 & \\
\hline
\end{tabular}

Sumber: Hasil Olah Data dengan SPSS (2021)

Untuk variabel kepuasan guru diukur dengan 5 butir pernyataan, dengan hasil uji validitas;

Tabel 5. Uji Coba Validitas Instrumen untuk Variabel Kepuasan kerja guru

\begin{tabular}{|c|l|c|c|c|}
\hline Butir & \multicolumn{1}{|c|}{ Pernyataan } & r-hitung & r-min & Keputusan \\
\hline 1 & $\begin{array}{l}\text { Gaji yang saya terima sudah sesuai dengan tugas } \\
\text { yang saya kerjakan. }\end{array}$ & 0,567 & 0,300 & Valid \\
\hline 2 & $\begin{array}{l}\text { Tugas yang diberikan terasa menarik dan } \\
\text { menyenangkan. }\end{array}$ & 0,783 & 0,300 & Valid \\
\hline 3 & $\begin{array}{l}\text { Jika saya bekerja dengan baik saya akan } \\
\text { promosikan. }\end{array}$ & 0,814 & 0,300 & Valid \\
\hline 4 & $\begin{array}{l}\text { Atasan (Kepala Sekolah) selalu memberikan } \\
\text { dukungan kepada saya. }\end{array}$ & 0,793 & 0,300 & Valid \\
\hline 5 & $\begin{array}{l}\text { Ketika saya meminta teman sekerja melakukan } \\
\text { sesuatu, akan dikerjakan dengan baik. }\end{array}$ & 0,678 & 0,300 & Valid \\
\hline
\end{tabular}

Sumber: Hasil olah data penelitian dengan SPSS (2021)

Dari hasil perhitungan validitas variabel kepuasan kerja guru ini, tampak semua butir pernyataan valid. Hal ini terjadi karena nilai $\mathrm{r}_{\text {-hitung }}$ diatas kriteria $\mathrm{r}$-minimal. Sehingga dapat mengukur variabel kepuasan kerja guru.

Tabel 6. Uji Coba Validitas Instrumen untuk Variabel Kinerja guru

\begin{tabular}{|c|c|c|c|c|}
\hline Butir & Pernyataan & r-hitung & r-min & Keputusan \\
\hline 1 & $\begin{array}{l}\text { Di awal semester guru menjelaskan materi apa } \\
\text { saja yang akan di ajarkan. }\end{array}$ & 0,736 & 0,300 & Valid \\
\hline 2 & $\begin{array}{l}\text { Sebelum pelajaran dimulai, guru menjelaskan } \\
\text { tujuan pembelajaran dari materi yang akan } \\
\text { diajarkan. }\end{array}$ & 0,594 & 0,300 & Valid \\
\hline 3 & $\begin{array}{l}\text { Guru mengunakan media (alat) yang sesuai } \\
\text { dengan materi yang diajarkan. }\end{array}$ & 0,757 & 0,300 & Valid \\
\hline 4 & $\begin{array}{l}\text { Guru menguasai materi pelajaran yang akan } \\
\text { diajarkan. }\end{array}$ & 0,756 & 0,300 & Valid \\
\hline 5 & $\begin{array}{l}\text { Guru memberikan kesempatan kepada siswa } \\
\text { untuk bertanya mengenai pelajaran yang } \\
\text { diajarkan. }\end{array}$ & 0,828 & 0,300 & Valid \\
\hline 6 & $\begin{array}{l}\text { Bapak/ibu guru menggunakan metode (cara) } \\
\text { yang sesuai dengan materi pelajaran yang } \\
\text { diajarkan. }\end{array}$ & 0,741 & 0,300 & Valid \\
\hline 7 & $\begin{array}{l}\text { Guru memberikan tugas setiap pelajaran yang } \\
\text { sudah selesai di ajarkan. }\end{array}$ & 0,654 & 0,300 & Valid \\
\hline 8 & $\begin{array}{l}\text { Guru melaksanakan evaluasi pembelajaran } \\
\text { (ulangan/ujian) sesuai dengan jadwal yang sudah } \\
\text { ditetapkan. }\end{array}$ & 0,757 & 0,300 & Valid \\
\hline 9 & Guru memberikan nilai secara objektif. & 0,570 & 0,300 & Valid \\
\hline 10 & $\begin{array}{l}\text { Guru membuat laporan hasil pembelajaran } \\
\text { (Raport) kepada orang tua siswa. }\end{array}$ & 0,634 & 0,300 & Valid \\
\hline
\end{tabular}

Sumber: Hasil olah data penelitian dengan SPSS (2021)

Dari hasil perhitungan validitas variabel kinerja guru ini, tampak semua butir pernyataan valid. Hal ini terjadi karena nilai $\mathrm{r}_{\text {-hitung }}$ diatas kriteria r-minimal. Sehingga dapat mengukur variabel kinerja guru.

Selanjutnya dilakukan uji reliabilitas interumen, bertujuan untuk menguji kehandalan atau kepercayaan pengungkapan data. Pengukuran yang memiliki reliabilitas tinggi adalah pengukuran yang mampu memberikan hasil yang dipercaya (reliable). Data yang valid diolah dengan teknik tertentu, dalam hal ini yang digunakan adalah teknik Alpha Cronbach. Suatu data dikatakan reliabel jika memberikan nilai Cronbach's Alpha > 0,60 (Ghozali, 2003). Hasil uji reliabilitas semua variabel ditunjukkan dalam tabel berikut:

Tabel 7. Hasil Uji Reliabilitas Instrumen Variabel

\begin{tabular}{|c|c|c|c|}
\hline Variabel & Cronbach's Alpha & $\mathrm{N}$ of Items & Keterangan \\
\hline - $\quad$ Kepemimpinan Kepsek & 0,800 & 9 & Reliabiltas Tinggi \\
\hline
\end{tabular}




\begin{tabular}{|c|c|c|c|}
\hline - $\quad$ Motivasi kerja guru & 0,801 & 4 & Reliabiltas Sedang \\
\hline - $\quad$ Kepuasan kerja guru & 0,827 & 5 & Reliabiltas Cukup \\
\hline - $\quad$ Kinerja Guru & 0,891 & 10 & Reliabiltas Tinggi \\
\hline
\end{tabular}

Sumber : Hasil olah data penelitian dengan SPSS (2021)

Menurut Sekaran (2006), bahwa reabilitas yang kurang dari 0,6 adalah kurang baik, sedangkan 0,7 dapat diterima dan reliabilitas dengan Cronbach's Alpha 0,8 atau di atasnya adalah lebih baik. Berdasarkan output yang diperoleh dari tabel di atas, diperoleh nilai koefisien reliabilitas pada semua variabel adalah realiable, dan hasilnya tinggi dan sedang.

\section{c. Hasil analisis Deskriptif}

Secara deskriptif akan diukur persepsi guru SMKN 1 Simpang Mamplam Kebupaten Bireuen tentang varibel yang diteliti sehingga mendapatkan gambaran mengenai suatu data yang akan diteliti atau untuk menguraikan kecenderungan jawaban responden dari tiap-tiap variabel. Hasilnya, sebagai berikut.

Tabel 8. Deskripsi Pegawai tentang Variabel Penelitian

\begin{tabular}{|l|c|c|c|c|c|c|}
\hline \multirow{2}{*}{ Variabel } & \multicolumn{4}{|c|}{ Persentase Jawaban setiap item (Jumlah) } & \multirow{2}{*}{ Skor } \\
\cline { 2 - 6 } & STS & TS & N & S & SS & Peapaian \\
\hline - Gaya Kepemimpinan & $\begin{array}{c}0,00 \\
(0)\end{array}$ & $\begin{array}{c}0,23 \\
(1)\end{array}$ & $\begin{array}{c}4,63 \\
(20)\end{array}$ & $\begin{array}{c}74,10 \\
(320)\end{array}$ & $\begin{array}{c}21,06 \\
(91)\end{array}$ & $\mathbf{8 3 , 1 9}$ \\
\hline - Motivasi & $\begin{array}{c}0,00 \\
(0)\end{array}$ & $\begin{array}{c}0,52 \\
(1)\end{array}$ & $\begin{array}{c}9,38 \\
(18)\end{array}$ & $\begin{array}{c}74,50 \\
(143)\end{array}$ & $\begin{array}{c}15,60 \\
(30)\end{array}$ & $\mathbf{8 1 , 0 4}$ \\
\hline - Kepuasan Kerja & 0,00 & $\begin{array}{c}0,40 \\
(0)\end{array}$ & $\begin{array}{c}6.67 \\
(16)\end{array}$ & $\begin{array}{c}77,08 \\
(185)\end{array}$ & $\begin{array}{c}15,83 \\
(38)\end{array}$ & $\mathbf{8 1 , 6 6}$ \\
\hline - Kinerja guru & 0,21 & $\begin{array}{c}0,00 \\
(1)\end{array}$ & $\begin{array}{c}9,17 \\
(4)\end{array}$ & $\begin{array}{c}75,20 \\
(361)\end{array}$ & $\begin{array}{c}15,63 \\
(75)\end{array}$ & $\mathbf{8 1 . 2 9}$ \\
\hline
\end{tabular}

Sumber : Hasil Peneltian, 2021 (data diolah, dengan SPSS)

Catatan : SS = Sangat setuju, $S=$ Setuju, $K S=$ Kurang setuju, $T S=$ Tidak setuju STS = Sangat tidak setuju)

Berdasarkan tabel di atas dapat dijelaskan bahwa :

1) Variabel gaya kepemimpinan, menurut persepsi guru di SMKN 1 Simpang Mamplam Kabupaten Bireuen, sudah baik, mencapai 83,19\% walaupun masih harus dioptimalkan lagi.

2) Variabel Motivasi, menurut persepsi guru di SMKN 1 Simpang Mamplam Kabupaten Bireuen, sudah baik, mencapai $81,04 \%$ walaupun dan harus ditingkatkan lagi.

3) Variabel kepuasan kerja, menurut persepsi guru di SMKN 1 Simpang Mamplam Kabupaten Bireuen, sudah baik, mencapai $81.66 \%$ sehingga $\mathrm{n}$ masih harus ditingkatkan lagi.

4) Variabel kinerja guru, menurut penilaian sebagian responden di SMKN 1 Simpang Mamplam Kabupaten Bireuen, sudah baik, mencapai 81,29\% dan harus terus di tingkatkan.

\section{d. Hasil Analisis Jalur}

Data penelitian terhadap 48 guru di SMK Negeri 1 Simpang Mamplam Kabupaten Bireuen, dengan instrument yang telah diuji validitas dan reabilitasnya. Hasil pendataan ditunjukkan dalam lampiran 4. Dalam penelitian ini model analisis dengan analisi jalur yang menentukan pengaruh variabel Gaya Kepemimpinan $\left(\mathrm{X}_{1}\right)$, Motivasi $\left(\mathrm{X}_{2}\right)$, dan Kepuasan $\operatorname{Kerja}\left(\mathrm{X}_{3}\right)$ terhadap Kinerja guru $(\mathrm{Y})$ dengan model $\mathrm{Y}=$ $\rho_{1} X_{1}+\rho_{2} X_{2}+\rho_{3} X_{3}+$ e. Adapun pembuktian hipotesis secara simultan (keseluruhan) dapat dilihat pada tabel berikut ini:

\section{Tabel 9. Uji Model Analisis Secara Simultan}

\begin{tabular}{|c|l|c|c|c|c|c|}
\hline \multicolumn{2}{|l|}{ Model } & Sum of Squares & df & Mean Square & F & Sig. \\
\hline \multirow{2}{*}{} & Regression & 1045.705 & 3 & 348.568 & 22.495 & $.000^{\mathrm{a}}$ \\
\cline { 2 - 7 } & Residual & 681.788 & 44 & 15.495 & & \\
\cline { 2 - 7 } & Total & 1727.493 & 47 & & & \\
\hline
\end{tabular}

a. Dependent Variable: Kinerja Guru (Y)

b. Predictors: (Constant), Kepuasan Kerja (X3), Gaya Kepemimpinan (X1), Motivasi (X2)

Berdasarkan hasil uji $\mathrm{F}$ diperoleh nilai $\mathrm{F}_{\text {hitung }}$ sebesar 22,495. Sementara nilai signifikansinya 0,000. Hal ini menunjukkan model regresi antar variabel signifikansi linier. Maka model analisi jalur dalam bentuk $\mathrm{Y}=$ $f(X 1, X 2, X 3)=\rho_{1} X_{1}+\rho_{2} X_{2}+\rho_{3} X_{3}$ dapat diterima.

\section{1). Pengujian Hipotesis Penelitian}


Dalam hal ini hipotesis yang diajukan selanjutnya diuji untuk menjawab masalah penelitian yang dirumuskan. Hasil pengolahan data dalam menaksir koefisiein jalur dan uji signifikansinya;

Tabel 10. Taksiran Koefisien Jalur Variabel Bebas (Eksogenus) dan Uji-t

\begin{tabular}{|l|c|c|c|}
\hline \multirow{3}{*}{ Model } & Unstandardized Coefficients & $\mathrm{t}$ & \multirow{2}{*}{ Sig. } \\
\cline { 2 - 2 } & Beta & & \\
\hline Gaya Kepemimpinan & 0.380 & 3.420 & 0.001 \\
\hline Motivasi & 0.297 & 2.353 & 0.023 \\
\hline Kepuasan & 0.267 & 2.110 & 0.041 \\
\hline
\end{tabular}

a. Dependent Variable: Kinerja

Uji hipotesis:

Hipotesis-1:

Ho: $\rho_{\mathrm{zx} 1} \leq 0$ : Gaya Kepemimpinan tidak berpengaruh terhadap Kinerja guru

$\mathrm{H}_{1}: \rho_{\text {zx1 }}>0$ : Gaya Kepemimpinan berpengaruh terhadap Kinerja guru

Kriteria pengujian adalah total Ho jika $t_{\text {hitung }}>t_{\text {tabel }}$ dimana $t_{\text {tabel }}$ untuk $\alpha=5 \%$ adalah 2,021. Dengan demikian $t_{\text {hitung }}>t_{\text {tabel }}(3,420>2,021)$. Hipotesis ini menyatakan ada pengaruh Gaya Kepemimpinan $\left(X_{1}\right)$ terhadap Kinerja guru (Y) secara signifikan pada taraf uji $\alpha=0,05$.. Dengan koefisien jalurnya $\rho_{\mathrm{yx} 1}=0,380$.

Hipotesis 2

Ho: $\rho_{\mathrm{yx} 2} \leq 0$ : Motivasi tidak berpengaruh terhadap Kinerja guru

$\mathrm{H}_{1}: \rho_{\mathrm{yx} 2}>0$ : Motivasi berpengaruh terhadap Kinerja guru

Hipotesis ini menyatakan ada pengaruh motivasi $\left(\mathrm{X}_{2}\right)$ terhadap Kinerja guru $(\mathrm{Y})$. Dengan koefisien jalurnya $\rho_{\mathrm{yx} 2}=0,297$. Hasil perhitungan uji individu menunjukkan harga $\mathrm{t}_{\text {hitung }}$ sebesar 2,353. Dengan demikian $\mathrm{t}_{\text {hitung }}$ $>\mathrm{t}_{\text {tabel }}(2,353>2,021)$. Sehingga $\mathrm{H}_{1}$ diterima, yang artinya koefisien jalur variabel motivasi $\left(\mathrm{X}_{2}\right)$ berpengaruh terhadap Kinerja guru (Y) secara signifikan pada taraf uji $\alpha=0,05$..

Hipotesis 3

Ho: $\rho_{\mathrm{yz} 3} \leq 0$ : Kepuasan kerja tidak berpengaruh terhadap Kinerja guru

$\mathrm{H}_{1}: \rho_{\mathrm{yx} 3}>0$ : Kepuasan kerja berpengaruh terhadap Kinerja guru

Hipotesis ini menyatakan ada pengaruh kepuasan kerja berpengaruh terhadap Kinerja guru (Y). Dengan koefisien jalurnya $\rho_{\text {zyx } 3}=0,267$. Hasil perhitungan uji individu menunjukkan harga $t_{\text {hitung }}$ sebesar 2,110 . Dengan demikian $t_{\text {hitung }}>t_{\text {tabel }}(2,110>2,021)$. Sehingga $H_{1}$ diterima artinya koefisien jalur variabel kepuasan kerja $\left(\mathrm{X}_{3}\right)$ berpengaruh terhadap Kinerja guru (Y), secara signifikan pada taraf uji $\alpha=0,05$.

\section{2). Menentukan Model Struktural}

Setelah terbukti adanya hubungan dan pengaruh secara signifikans antara variabel eksogen terhadap variabel endogen dalam penelitian ini, lalu dilakukan taksiran nilai kausalitas antar variabel eksogen $\left(\mathrm{X}_{1}\right.$, $\mathrm{X}_{2}, \mathrm{X}_{3}$ ) pada tabel 11, yakni :

Tabel 11. Hubungan Kausal Antar Variabel Bebas (Eksogenus)

\begin{tabular}{|l|l|c|c|c|}
\hline \multirow{3}{*}{ Gaya Kepemimpinan } & & Gaya Kepemimpinan & Motivasi & Kepuasan \\
\cline { 2 - 5 } & Pearson Correlation & 1 & $.468^{* *}$ & $.474^{* * *}$ \\
\cline { 2 - 5 } & Sig. (2-tailed) & & .001 & .001 \\
\hline \multirow{2}{*}{ Motivasi } & Pearson Correlation & $.468^{* *}$ & 1 & $.632^{* *}$ \\
\cline { 2 - 5 } & Sig. (2-tailed) & .001 & .000 \\
\hline & Pearson Correlation & $.474^{* *}$ & $.632^{* *}$ & 1 \\
\cline { 2 - 5 } & Sig. (2-tailed) & .001 & .000 & \\
\hline
\end{tabular}

**. Correlation is significant at the 0.01 level (2-tailed).

Berdasarkan antar variabel eksogen, dan nilai koefisien jalur $(\rho)$, maka model kausal yang dibentuk secara teoritik diperoleh diagram jalur seperti gambar 2 .

Abd Fata, Mohd. Ilyas | Pengaruh Gaya Kepemimpinan K

Keterangan :

$\mathrm{Y}=$ Kinerja guru

$\mathrm{X}_{1}=$ Gaya Kepemimpinan Kepala Sekolah

$\mathrm{X}_{2}=$ Motivasi guru

$\mathrm{X}_{3}=$ Kepuasan kerja

$\varepsilon=$ Epsilon, yaitu menunjukkan variabel atau faktor residual yang menjelaskan pengaruh variabel lain yang tidak diteliti.

$r_{x i, x j}=$ hubungan kausal antar variabel eksogen di ukur dengan koefisien korelasi

$\rho_{\mathrm{yxi}}=$ Nilai Koefisien Jalur $($ Path $)$ 


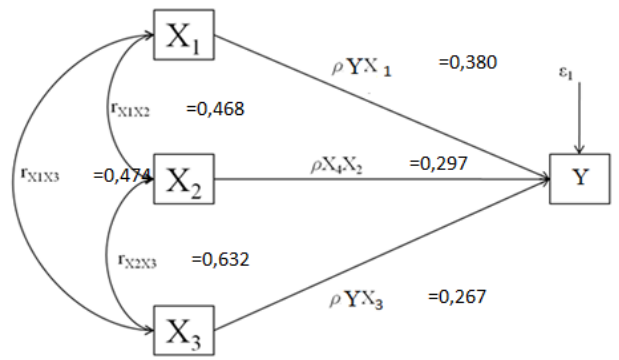

Gambar 2. Diagram Jalur Penelitian

\section{d. Pembahasan}

\section{1). Pengaruh Gaya Kepemimpinan Kepala Sekolah terhadap Kinerja Guru}

Hasil analisis data sebelumnya, menunjukkan adanya pengaruh Kepemimpinan Kepala Sekolah terhadap kinerja guru. Adapun besarnya pengaruh, langsung ataupun tidak langsung karena terdapat hubungan kausalitas antara variabel Kepemimpinan dengan motivasi dan kepuasan kerja, ditentukan berikut ini: Besarnya pengaruh langsung gaya kepemimpinan $\left(\mathrm{X}_{1}\right)$ terhadap kinerja guru $(\mathrm{Y})$, dinyatakan dengan besaran koefisien jalur $\left(\rho_{\mathrm{yx} 1}=380\right)$, Sehingga besarnya pengaruh langsung ini adalah: $(0,380)^{2} \times 100 \%=$ $14,44 \%$.

Besarnya pengaruh tidak langsung:

- Pengaruh gaya kepemimpinan $\left(\mathrm{X}_{1}\right)$ melalui motivasi $\left(\mathrm{X}_{2}\right)$ terhadap Kinerja guru(Y), adalah = $(0,380)(0,468)(0,297) \times 100 \%=5,28 \%$

- Pengaruh gaya kepemimpinan $\left(\mathrm{X}_{1}\right)$ melalui kepuasan kerja $\left(\mathrm{X}_{3}\right)$ terhadap Kinerja guru(Y)adalah = $(0,380)(0,474)(0,267) \times 100 \%=4,81 \%$

Maka Pengaruh Total Gaya Kepemimpinan Kepala Sekolah $\left(\mathrm{X}_{1}\right)$ terhadap kinerja guru adalah 24,53 persen.

\section{2). Pengaruh Motivasi terhadap Kinerja Guru}

Hasil analisis data sebelumnya, menunjukkan adanya pengaruh motivasi terhadap kinerja guru. Adapun besarnya pengaruh langsung ataupun tidak langsung karena terdapat hubungan kausalitas antara variabel eksogen, ditentukan berikut ini:

Besarnya pengaruh langsung motivasi $\left(\mathrm{X}_{2}\right)$ terhadap Kinerja guru $(\mathrm{Y})$, dinyatakan dengan besaran koefisien jalur $\left(\rho_{\mathrm{yx} 2}=0,297\right)$, Sehingga besarnya pengaruh langsung ini adalah: $(0,297)^{2} \mathrm{x} 100 \%=8,82 \%$.

Besarnya pengaruh tidak langsung:

- Pengaruh motivasi $\left(\mathrm{X}_{2}\right)$ melalui gaya kepemimpinan $\left(\mathrm{X}_{1}\right)$ terhadap kinerja guru(Y), adalah = $(0,297)(0,469)(0,380) \times 100 \%=5,28 \%$

- Pengaruh motivasi $\left(\mathrm{X}_{2}\right)$ melalui kepuasan kerja $\left(\mathrm{X}_{3}\right)$ terhadap kinerja guru $(\mathrm{Y})$ adalah = $(0,297)(0,632)(0,267) \times 100 \%=5,01 \%$

Maka Pengaruh Total motivasi $\left(\mathrm{X}_{2}\right)$ terhadap kinerja guru $(\mathrm{Y})$ adalah 19,12 persen.

\section{3). Pengaruh Kepuasan kerja terhadap Kinerja huru}

Hasil analisis data sebelumnya, menunjukkan adanya pengaruh kepuasan kerja terhadap kinerja guru. Maka besarnya pengaruh langsung ataupun tak langsnung, ditentukan berikut ini:

Besarnya pengaruh langsung kepuasan kerja $\left(\mathrm{X}_{3}\right)$ terhadap Kinerja guru $(\mathrm{Y})$, dinyatakan dengan besaran koefisien jalur $\left(\rho_{\mathrm{yx} 3}=0,267\right)$, Sehingga besarnya pengaruh langsung ini adalah: $(0,267)^{2} \times 100 \%=7,13 \%$.

Besarnya pengaruh tidak langsung:

- Pengaruh kepuasan kerja $\left(\mathrm{X}_{3}\right)$ melalui gaya kepemimpinan $\left(\mathrm{X}_{1}\right)$ terhadap Kinerja guru( $\left.\mathrm{Y}\right)$, adalah = $(0,267)(0,474)(0,380) \times 100 \%=4,81 \%$

- Pengaruh kepuasan kerja $\left(\mathrm{X}_{3}\right)$ melalui motivasi $\left(\mathrm{X}_{2}\right)$ terhadap kinerja guru $(\mathrm{Y})$ adalah = $(0,267)(0,632)(0,297) \times 100 \%=5,01 \%$

Maka pengaruh Total Kepuasan kerja $\left(\mathrm{X}_{3}\right)$ terhadap kinerja guru $(\mathrm{Y})$, adalah dengan 16,95 persen.

\section{4). Pengaruh Gaya Kepemimpinan Kepala Sekolah, Motivasi dan Kepuasan kerja terhadap Kinerja Guru}

Berdasarkan model struktural yang dikaji dan dibahas sebelumnya, maka dapat di perdalam dengan melibatkan ketiga faktor yang diduga berpengaruh pada kinerja pegawai, yakni faktor Gaya Kepemimpinan Kepala sekolah, motivasi dan kepuasan kerja terhadap kinerja guru secara simultan, yakni dengan 
menghitung korelasi dan determinasi antar variabel ini, yakni sebagai berikut:

a). Korelasi antar Gaya Kepemimpinan Kepala sekolah, Motivasi dan Kepuasan kerja terhadap kinerja guru secara simultan

Tabel 12. Korelasi dan Determinasi antar variabel

\begin{tabular}{|c|c|c|c|}
\hline $\mathrm{R}$ & R Square & Adjusted R Square & Std. Error of the Estimate \\
\hline $.778^{\mathrm{a}}$ & .605 & .578 & 3.936391 \\
\hline
\end{tabular}

Maka dari informasi diatas, terdapat sebesar 0,778 korelasi antar variabel Gaya Kepemimpinan Kepala sekolah, Motivasi dan Kepuasan kerja terhadap kinerja guru,. Ini menunjukkan hubungan yang cukup tinggi dengan derajat 0,778 dan hubungannya positip.

Dan Hasil koefsiein determinasinya $\left(\mathrm{R}^{2}\right)$ adalah sebesar 0,605 yang maknainya terdapat sebesar $60,5 \%$ kontribusi atau peranan adanya faktor Gaya Kepemimpinan Kepala sekolah yang sesuai, Motivasi guru guru positif dan Kepuasan kerja terhadap kinerja guru. Dan sisanya yakni sekitar 39,5\% dipengaruhi oleh faktor lain, seperti kompensasi, budaya kerja dan pelatihan, atau lainnya yang mengikat terhadap kinerja guru.

\section{Simpulan (Conclusion)}

Sebagaimana tujuan dari penelitian ini, maka dari hasil penelitian dan pembahasan yang dilakukan, dapat ditarik beberapa simpulan penting sebagai rangkuman dan temuan hasil penelitian, yakni:

1) Hasil analisis dari data penelitian, menunjukkan adanya pengaruh faktor Gaya kepemimpinan terhadap Kinerja guru SMK Negeri 1 Simpang Mamplam.Kabupaten Bireuen, yakni sebesar 24,53\%.

2) Hasil analisis dari data penelitian juga membuktikan adanya pengaruh faktor Motivasi terhadap Kinerja guru di SMK Negeri 1 Simpang Mamplam.Kabupaten Bireuen, yakni sebesar 19,12\%.

3) Dan dari hasil analisis data penelitian selanjutnya, menunjukkan adanya pengaruh faktor Kepuasan kerja terhadap Kinerja guru di SMK Negeri 1 Simpang Mamplam.Kabupaten Bireuen, yakni sebesar, yakni sebesar $16,95 \%$.

4) Hasil analisis deskriptif, menemukan bahwa, a). Faktor gaya kepemimpinan, menurut persepsi guru di SMK Negeri 1 Simpang Mamplam, sudah baik, mencapai 83,19\% waluapun masih harus dioptimalkan lagi. b). Faktor motivasi dianggap oleh sebagain guru sudah baik dalam mendukung kinerja guru. Skor penilaian guru atas motivasi mencapai $81,04 \%$, c). Faktor kepuasan kerja, menurut penilaian guru, juga hampir mendekati optimal, yaitu mencapai $81,66 \%$. d). Tingkat Kinerja guru mencapai kategori baik, yakni $81,29 \%$.

5) Hasil nilai koefisien determinasi menjelaskan bahwa kontribusi faktor Gaya kepemimpinan, Motivasi dan Kepuasan kerja terhadap Kinerja guru SMK Negeri 1 Simpang Mamplam sebesar 60,50\%. Sementara sisanya (nilai residu) dari peran variabel yang tidak di teliti sebesar 39,50\%. Hal ini menujukkan bahwa terdapat faktor-faktor lain yang dapat mempengaruhi variabel kinerja guru, seperti Iklim organisasi, kompensasi, Budaya organisasi, Fasilitas kerja, Pendidikan dan Latihan dan lain-lain.

\section{DAFTAR PUSTAKA (References)}

1) Achmad Taviv Junaedi, 2010, Analisis Pengaruh Kualitas Pelayanan, Keadilan dan Kepuasan Nasabah Terhadap Loyalitas Nasabah Bank Syariah (Studi Pada Nasabah Bank Syariah Provinsi Riau), Jurnal Ilmu Ekonomi Dan Bisnis Program Doktor Universitas Brawijaya Malang

2) Arief, Sritua. 1993. Metodologi Penelitian Ekonomi. Universitas Indonesia. Jakarta.

3) Buchari Zainun, 2009. Manajemen Sumber Daya Manusia. Yogyakarta : Graha Ilmu. Andri

4) Edy Sutrisno, 2009. Manajemen Sumber Daya Manusia. Kencana. Jakarta

5) Gibson, M. 2008. Manajemen Sumber Daya Manusia. Cetakan ke dua. Jakarta: Erlangga

6) Karyadi, M. 1983. Kepemimpinan (Leadership). Bandung: Karya Nusantara.

7) Keiningham, Timothy L., et al. 2007. The Value of Different Customer Satisfaction and Loyalty Metrics in Predicting Customer Retention, Recommendation, and Share-of-Wallet. Managing Service Quality.

8) Khaerul Umam. 2010. Perilaku Organisasi. Bandung: Pustaka Setia

9) Luthans, F. 2006. Perilaku Organisasi. Edisi Sepuluh. Yogyakarta : ANDI

10) Mangkunegara, A. A. A. P., 2009., Manajemen Sumber Daya Manusia Perusahaan, Bandung, PT. Remaja Rosda karya.

11) Marwan Hamid, Ibrahim Sufi, Win Konadi, dan Yusrizal Akmal, 2019. Analisis Jalur Dan Aplikasi Spss Versi 25, Edisi Pertama Sefa Bumi Persada, Medan. 
12) Misbahuddin dan Iqbal Hasan. 2013. Analisis Data Penelitian dengan Statistik. Edisi Ke-2. Cetakan Ke-2. Jakarta: PT Bumi Aksara

13) Mulyasa. 2003. Kurikulum Berbasis Kompetensi. Bandung: Remaja Rosda. Karya

14) Munandar.2010. Budgeting, Perencanaan Kerja, Pengkoordinasian Kerja dan Pengawasan Kerja. Yogyakarta: BPFE UniversitasGajahmada

15) Nawawi, Hadari, 2005, Manajemen Sumber daya Manusia. Cetakan keempat. Jogjakarta: Penerbit Gadjah Mada University Press

16) Rivai, Veithzal. 2004, Manajemen Sumber Daya Manusia. Jakarta : Raja. Grafindo

17) Roelen, C. A. M., Koopmans, P. C., \& Groothoff, J. W. 2008. Which Work Factors Determine Job Satisfaction. Work, 4, 433-439.

18) Rusyan, H.A. Tabrani. 2013. Membangun Guru Berkualitas. Jakarta: PT. Pustaka Dinamika

19) Sedarmayanti. 2011. Tata Kerja dan Produktivitas Kerja. Bandung: CV. Mandar Maju.

20) Siagian, S.P. 2003, Manajemen Sumber Daya Manusia. Jakarta: PT BumiAksara.

21) Sugiyono 2013. Statistika Untuk Penelitian. Alfabeta. Bandung.

22) Sudjana, Nana. 2004. Dasar-dasar Proses Belajar Mengajar. Bandung :Sinar. Baru Algensido Offset.

23) Surya, Mohamad. 2004. Psikologi Pembelajaran dan Pengajaran. Bandung: Pustaka. Bani

24) Soetopo. 2012,Perilaku Organisasi Teori dan Praktik di. Bidang Pendidikan (Cetakan kedua). Bandung: Rosda.

25) Wahjosumidjo. 2001. Kepemimpinan Kepala Sekolah. Jakarta: PT Radja Grafindo

26) Winardi. 2008. Motivasi dan Pemotivasian Dalam Manajemen, Jakarta: Raja.

27) Yamin dan Maisah. 2010. Standarisasi Kinerja Guru, Jakarta: GP Press

28) Neraca Pendidikan Daerah, Kemendikbud, 2019).

29) Departemen Pendidikan Nasional ; 2008 